\title{
Ecophysiological and anatomical changes due to uptake and accumulation of heavy metal in Brachiaria decumbens
}

\author{
Marcelo Pedrosa Gomes ${ }^{1}$, Teresa Cristina Lara Lanza de Sá e Melo Marques ${ }^{2}$, Mariana de Oliveira \\ Gonçalves Nogueira ${ }^{3}$, Evaristo Mauro de Castro ${ }^{3}$, Ângela Maria Soares ${ }^{3}$ * \\ ${ }^{1}$ UFMG/Inst. de Ciências Biológicas - Depto. de Botânica, C.P. 486 - 31279-901 - Belo Horizonte, MG - Brasil. \\ ${ }^{2}$ UFLA - Depto. de Ciência do Solo, C.P. 37 - 37200-000 - Lavras, MG - Brasil. \\ ${ }^{3} U F L A$ - Depto. de Biologia, Setor de Fisiologia Vegetal, C.P. 37 - 37200-000 - Lavras, MG - Brasil. \\ *Corresponding author < amsoares@dbi.ufla.br> \\ Edited by: Luis Reynaldo Ferracciú Alleoni
}

\begin{abstract}
The growth and developmental characteristics of grasses and their high biodiversity make such plants suitable for remediation of areas contaminated by heavy metals. Nevertheless, heavy metal toxic effect on the plants may cause alteration in their metabolic pathways, such as photosynthesis, respiration, and growth, modifying plant anatomy. This work aimed to evaluate the effect of levels of soil contamination $\left(0,7.5 \%\right.$ and $\left.15 \% \mathrm{~m}^{3} \mathrm{~m}^{-3}\right)$ on biomass production, on photosynthetic characteristics and on anatomical changes in roots and leaves of brachiaria (Brachiaria decumbens Stapf.). After seeds were planted, seedlings were uprooted and replanted in vases containing soil at different contamination levels, being left to rest for 120 days. At the end of that time, plants presented reduced yield of root and shoot dry matter, contents of chlorophyll $a$, chlorophyll $b$, total chlorophyll and potential photosynthesis with increased of soil contamination. The cell layers of endodermis and exodermis in the root tissues and the cell walls of the xylem and cortical parenchyma all thickened as contamination increased. In the leaf tissues, the adaxial and abaxial epidermis presented increased thickness while the leaf blade presented reduced thickness as contamination increased with consequent change in the root growth rate. In general, the effects of heavy metal increased with the metal concentration. Some results indicate that $B$. decumbens seems to have some degree of heavy metal tolerance. Keywords: contaminated soil, chlorophyll, growth, potencial photosynthesis
\end{abstract}

\section{Introduction}

Gramineous plants have shown potential for use in the recovery of areas degraded by heavy metals, due to the relative ease with which they develop and therefore, promoting fast and dense covering of the soil, improving its physical structure, attenuating erosion and adding organic matter (Carneiro et al., 2001).

The phytotoxic effect of heavy metals in plants manifests itself through visual symptoms such as chlorosis, necrosis and wilting, and through reduced growth and biomass accumulation (Marques et al., 2000; Sanitá di Troppi and Gabbrielli, 1999). Physiological effects have also been noted in plants exposed to contamination at various levels of the photosynthetic process, including the chlorophyll biosynthesis (Chugh and Sawhney, 1999), the dynamics of photochemical reactions (SkorzynskaPolit et al., 2003) and the activity of Calvin cycle enzymes (Cagno et al., 1999).

When penetrating the roots, heavy metals are predominantly accumulated and translocated in the cell wall system (MacFarlane and Burchett, 2000), with the exodermis and the endodermis constituting an effective barrier to the movement of these ions (Ederli et al., 2004; Lux et al., 2004; Wójcik et al., 2005). Studying changes in leaf tissues also helps understand the process of metal accumulation and tolerance, since the absorption of these ions from the soil solution is closely related to the leaf transpiration rate. The effects of $\mathrm{Cd}$ on the leaf anatomy of Brassica juncea and Salix viminalis plants were discussed by Srighar et al. (2005) and by Vollenweider et al. (2006), respectively.

This study evaluated the effect of soil contamination by heavy metals on biomass production and characteristics asso- ciated to photosynthetic capacity, and on anatomical changes in roots and leaves of $B$. decumbens, and having as a goal to show some adaptive characteristics by species for survival in soil contaminated by heavy metals.

\section{Materials and Methods}

The study was carried out under a greenhouse, localized in Lavras (Minas Gerais State (MG), Brazil, 21 ${ }^{\circ} 14^{\prime}$ S, $45^{\circ} 00^{\prime}$ W, $918 \mathrm{~m}$ a.s.l). Soil samples from the heavy metals contaminated site was collected in a dump area of a zinc mining company located in Três Marias, MG, Brazil (18 ${ }^{\circ} 12^{\prime}$ S, 45 $5^{\circ} 13^{\prime}$ W, 585 $\mathrm{m}$ a.s.l.). Chemical analysis of the soil revealed the following contents (in $\mathrm{mg} \mathrm{kg}^{-1}$ of soil): $\mathrm{Zn}=18.600, \mathrm{Cd}=140, \mathrm{Cu}=$ 450 and $\mathrm{Pb}=410$, extracted with aqua regia (Forster, 1995). Treatments consisted of mixtures of this contaminated soil sample and soil material sampled from the 0-20 cm layer of an Oxisol from Lavras, MG, at concentrations $0 \%, 7.5 \%$ and $15 \% \mathrm{~m}^{3} \mathrm{~m}^{-3}$. The mixture containing $7.5 \%\left(\mathrm{~m}^{3} \mathrm{~m}^{-3}\right)$ of contaminated soil presented the following heavy metals (in $\mathrm{mg}$ $\mathrm{kg}^{-1}$ ): 10.5 of $\mathrm{Cd} ; 30.75$ of $\mathrm{Pb} ; 1.395$ of $\mathrm{Zn}$ and 33.75 of $\mathrm{Cu}$. The mixture containing $15 \%\left(\mathrm{~m}^{3} \mathrm{~m}^{-3}\right)$ of contaminated soil presented (in $\mathrm{mg} \mathrm{kg}^{-1}$ ): 21 of $\mathrm{Cd}$; 61.5 of $\mathrm{Pb} ; 2.790$ of $\mathrm{Zn}$, and 67.5 of $\mathrm{Cu}$. Each mixture received $400 \mathrm{mg} \mathrm{kg}^{-1}$ of P (simple superphosphate), evenly applied.

Seeds of $B$. decumbens were sown in polystyrene trays, and once they had reached around $10 \mathrm{~cm}$ in height they were transplanted into vases containing $6 \mathrm{~L}$ of the soil mixtures and then thinned. The species $B$. decumbens was selected as a representative of family Poaceae, which, according to Silva et al. (2006), has tolerance to heavy metals. Analyses were 
performed 120 days after treatment induction of phytomass accumulation, contents of chlorophyll $a$, chlorophyll $b$ and total chlorophyll, and potential photosynthesis $\left(\mathrm{A}_{\max }\right)$, along with anatomical evaluations. For determination of phytomass production, plants were gathered and separated into root and shoot fractions, then washed with distilled water, stored in paper bags and taken to an air circulation oven at $70^{\circ} \mathrm{C}$ until constant mass.

The quantification of chlorophyll $a$, chlorophyll $b$ and total chlorophyll was done according to Arnon (1949), using one fully expanded leaf per vase to a total of four replicates per treatment, all being immediately covered with aluminum foil and placed in a polystyrene box containing ice for pigment quantification. Potential photosynthesis was measured using an oxygen monitor equipped with a Clark electrode. Leaf discs were used from fully expanded leaves of three plants per treatment, with a corresponding source of light at the leaf discs level, at a photosynthetically active photon flow density of $1.500 \mu \mathrm{mol} \mathrm{m}^{-2} \mathrm{~s}^{-1}$ and a chamber temperature of $35^{\circ} \mathrm{C}$, using a solution $1 \mathrm{M}$ of $\mathrm{NaHCO}_{3}$ as a source of $\mathrm{CO}_{2}$.

For anatomical analyses, roots and the first fully expanded leaf of five individuals per treatment were collected, corresponding to each replicate. The material was fixed in FAA (formaldehyde + acetic acid + ethyl alcohol 70\% 5:5:90 L L ${ }^{-1}$ $\mathrm{L}^{-1}$ ) (Johansen, 1940) for 72 hours and then kept in ethyl alcohol $70 \%$.

A table microtome was used to obtain cross sections of the foliar mid third and $4 \pm 0.5 \mathrm{~cm}$ away from the root apex. Paradermal cuts were manually performed on the mid third of leaves. The cross sections were prepared with bleach $5 \%$ (Kraus and Arduim, 1997) and an astra blue and safranine staining mixture (Kraus and Arduim, 1997). The paradermal sections were stained with a safranine solution at $1 \%$. Glycerin $50 \%$ was used to mount the slides. All slides were examined and photographed using a Ken-a-Vision T'T18 light microscope and a Canon Power Shot A620 digital camera.

Lignin detection was done using fluorescence analyses. Cross sections $4 \pm 0.5 \mathrm{~cm}$ away from the root apex were stained with berberine hemi-sulfate at $0.1 \%\left(\mathrm{~kg} \mathrm{~m}^{-3}\right)$ for one hour (Brundrett et al., 1988). Sections were then washed with distilled water, transferred to a solution of blue aniline at 0.5 $\%\left(\mathrm{~kg} \mathrm{~m}^{-3}\right)$ for 30 minutes, and again washed with distilled water. The sections were incubated in a solution of $50 \%$ glycerin $\left(\mathrm{m}^{3} \mathrm{~m}^{-3}\right)$ and $0.1 \% \mathrm{FeCl}_{3}\left(\mathrm{~kg} \mathrm{~m}^{-3}\right)$ (Ederli et al., 2004) and washed with distilled water after a few minutes, then mounted on slides and examined under an Olympus BX60 microscope using UV light with a bandpass filter for wavelengths above $420 \mathrm{~nm}$.

The determination of anatomical characteristics was done using software Sigma Scan on three fields of five individuals per treatment. In the root system, items assessed included thickness of exodermis and endodermis and number of the protoxylem, cell wall thickness of tracheary elements and cortical cells, as well as the number and area of metaxylem elements. The area of metaxylem elements was given by the sum of areas of the latter metaxylem elements in the vascular cylinder.

In order to evaluate the leaf characteristics, the midrib was used as a benchmark, counting the number of conducting elements of the xylem and measuring the height and width of the vascular bundle. Thickness measurements were also taken of endodermis (bundle sheath), sclerenchyma of abaxial and adaxial surface, epidermis of adaxial and abaxial surface, leaf blade and bulliform cells. The area of metaxylem elements was determined by the sum of areas of three larger diameter metaxylem elements in the vascular bundle. Stomatic density was given by the number of stomata per $\mathrm{mm}^{2}$, also measuring the polar and equatorial diameters of stomata.

This study used a completely randomized experimental design. Data were submitted to analysis of variance, and means were compared by the Tukey test $(p \leq 0.05)$, using statistical application Sisvar 4.3 (Ferreira, 1999).

\section{Results and Discussion}

\section{Growth responses}

Phytomass production was affected by the soil contamination with heavy metals $(p \leq 0.05)$. A reduction was observed in the accumulation of root and shoot dry matter as well as in the total dry matter with the increase in contamination (Figure 1A). Taking into account the ratio of root to shoot dry matter $(\mathrm{R} / \mathrm{S})$, the contaminated treatments presented lower values, indicating that the root parts were more affected $(p \leq 0.05)$ by contamination than the shoot parts (Figure 1B).

The plants of the treatments exposed to contamination, particularly at $15 \%$, developed visual symptoms in response to heavy metal toxicity. Changes were noted in the architecture of the root system, with roots appearing darkened and thickened, and noting a significant decrease in root hair. These symptoms could partially justify the lower phytomass production in that a smaller volume of soil being explored can influence the nutrition and water balance in plants. Several authors have demonstrated the effect of heavy metals on plants resulting in reduced growth and phytomass accumulation (Barceló et al., 1990; Marques et al., 2000; Sandalio et al., 2001). In association, regarding the aerial part, chlorotic spots, leaf curling, reduced flexibility of the leaf blade, reduced growth and reduced emergence of leaves were observed. Visual symptoms developed by plants in response to heavy metals have been widely reported (Alloway and Ayres, 1997; Fontes and Cox, 1998; Kabata-Pendias and Pendias, 2001).

Contents of chlorophyll $a$, chlorophyll $b$ and total chlorophyll were lower and the chlorophyll $a / b$ ratio was higher in the treatment with contamination at $15 \%$ than in the other treatments, which did not differ $(p \leq 0.05)$ from each other (Table 1). Again in this treatment, precocious chlorotic spots were observed in the early stage of leaf development, maybe related to lower chlorophyll contents in this treatment. Significant decline in chlorophyll contents can justify the precocious emergence of chlorotic spots in young leaves of the treatment exposed to contamination at $15 \%$. The higher chlorophyll $a / b$ ratio presented by the treatment exposed to the highest contamination level indicates that the synthesis of chlorophyll $b$ was more strongly affected than that of chlorophyll $a$. The effect of metal ions on pigment production has been investigated in several species (Cagno et al., 1999; Chugh and Sawhney, 1999; Horváth et al., 1996). 
As contamination levels increased the potential photosynthetic rate decreased proportionally (Figure 2). Increased contamination reduced the photosynthetic rate by approximately $50 \%$ in the treatment exposed to $15 \%$ of contamination, at the end of the experimental period. Reduced photosynthetic activity is commonly observed in plants exposed to heavy metals (Chugh and Sawhney, 1999; Prasad et al., 2001). This has been attributed to the deleterious action of metals on chlorophyll synthesis (Stobart et al., 1985), on photosynthetic efficiency (Chugh and Sawhney, 1999), on enzyme activity (Singh et al., 2006), and on water balance (Zhou and Qiu, 2005). Photosynthesis is a key process for plant growth and biomass production has been used as bioindicator of stress (Sheoran
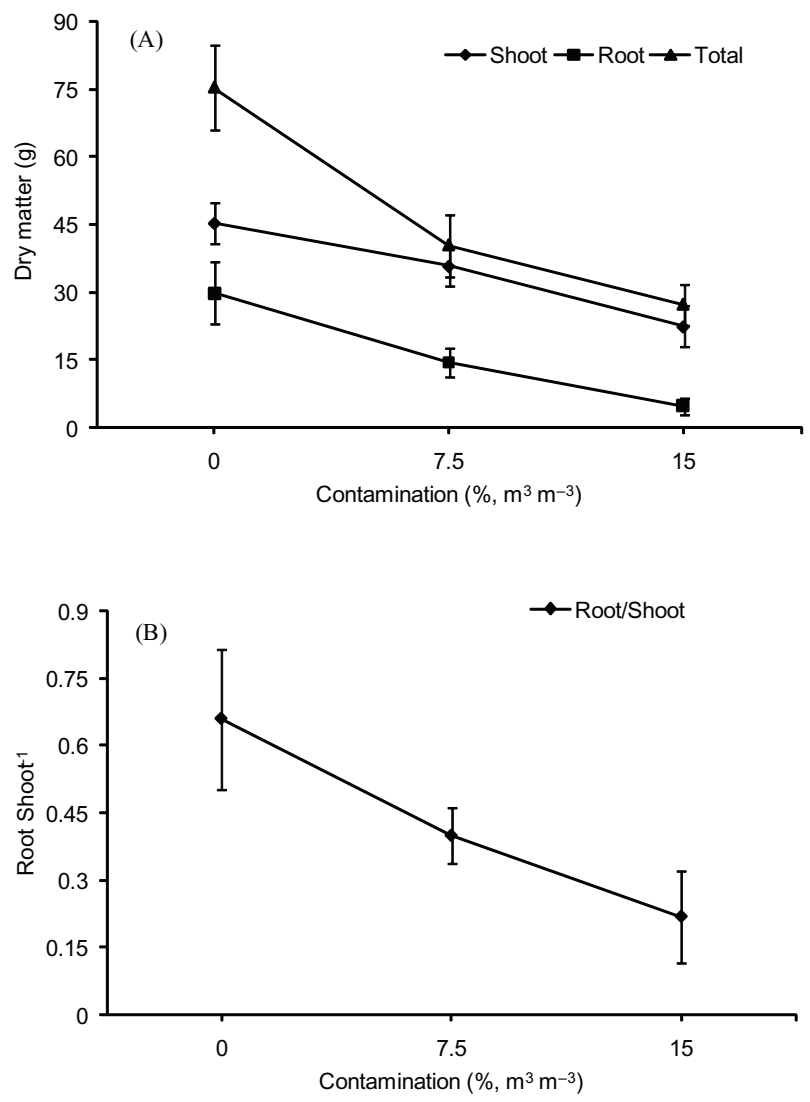

Figure 1 - Growth characteristics of $B$. decumbens plants submitted to levels of soil contamination from heavy metals. A. Dry matter in root, shoot and total dry matter. B. Root/Shoot. Bars indicate standard error of mean for three replicates. et al., 1990a,b). In this study photosynthesis was inhibited by the plants growing in the presence of contaminated soil (Figure 2). This deleterious effect on photosynthetic rates can be a result of global reduction in growth, with a concomitant decrease in leaf area, or else it can be a result of direct metal interference in hindering photosynthetic reactions (Chugh and Sawhney, 1999). Heavy metals are capable of affecting chlorophyll contents, the activity of Calvin cycle enzymes, while PSII is extremely sensitive to metal ions (Cagno et al., 1999; Cagno et al., 2001). In association, whether directly or indirectly, these factors all contribute to reduced carbon assimilation rates.

\section{Anatomical responses of the root}

The roots of $B$. decumbens plants presented uniseriate epidermis, with evenly sized cells and stratified exodermis, with three highly lignified cell layers, and uneven diameter cells. The endodermis presented a thickened U-shaped inner periclinal wall, the pericycle was highly lignified, and the pith parenchyma presented secondary thickening of the cell wall (Figure 4). Anatomical analyses revealed several changes in the root tissues of plants submitted to contaminated treatments. The root epidermis was degraded in the treatment exposed to the highest contamination level (Figure 4E). The root exodermis and endodermis were thickened in the treatments exposed to contamination (Table 2). Contamination accelerated the maturation of the cell wall in endodermis and exodermis (Figure 4).

The loss of epidermis tissue was apparently offseted by a thickened exodermis tissue (Table 2) and the maturation of exodermis cell walls (Figure 4C). The potential oxidative stress

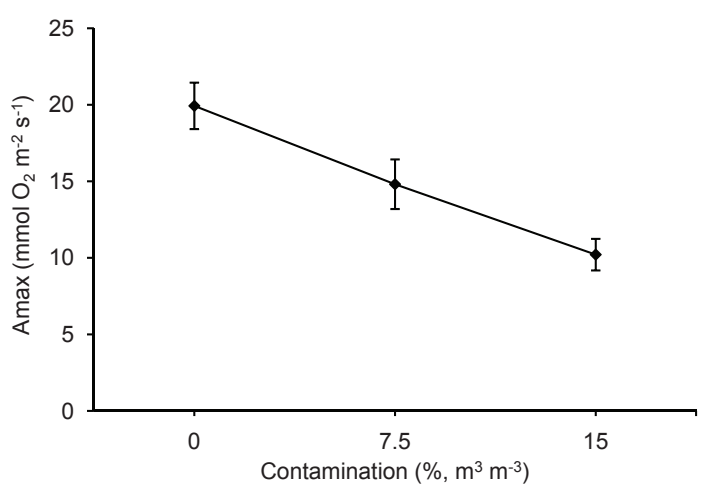

Figure 2 - Potential photosynthesis (Amax) of B. decumbens plants submitted to levels of soil contamination from heavy metals. Bars indicate standard error of mean for three replicates.

Table 1 - Content of chlorophyll $a$, chlorophyll $b$, total chlorophyll and chlorophyll $a / b$ ratio in $B$. decumbens plants submitted to levels of soil contamination from heavy metals.

\begin{tabular}{lcccc}
\hline Treatment & Chlorophyll $a$ & Chlorophyll b & Total chlorophyll & Chlorophyll $a / b$ \\
\hline Control & $16.8 \mathrm{a}$ & $6.5 \mathrm{a}$ & $23.2 \mathrm{a}$ & $2.5 \mathrm{~b}$ \\
Contamination at $7.5 \%$ & $16.2 \mathrm{a}$ & $5.7 \mathrm{a}$ & $21.9 \mathrm{a}$ & $2.6 \mathrm{ab}$ \\
Contamination at $15 \%$ & $4.6 \mathrm{~b}$ & $1.8 \mathrm{~b}$ & $6.3 \mathrm{~b}$ & $2.9 \mathrm{a}$ \\
\hline
\end{tabular}

Means followed by the same letter in the column do not differ (Tukey test, $p \leq 0.05 ; \mathrm{n}=4$ ). 
Table 2 - Anatomical characteristics of root tissues in $B$. decumbens plants submitted to levels of soil contamination from heavy metals.

\begin{tabular}{lrrr}
\hline & \multicolumn{3}{c}{ Treatment } \\
\cline { 2 - 4 } & \multicolumn{1}{c}{0} & 7.5 & 15 \\
\cline { 2 - 4 } & \multicolumn{3}{c}{ Contamination $\left(\%, \mathrm{~m}^{3} \mathrm{~m}^{-3}\right)$} \\
\hline Exodermis $(\mu \mathrm{m})$ & $55.8 \mathrm{~b}$ & $67.5 \mathrm{a}$ & $75.5 \mathrm{a}$ \\
\hline Endodermis $(\mu \mathrm{m})$ & $19.2 \mathrm{~b}$ & $26.7 \mathrm{a}$ & $26.9 \mathrm{a}$ \\
No. metaxylem elem. & $8.0 \mathrm{a}$ & $9.6 \mathrm{a}$ & $9.8 \mathrm{a}$ \\
\hline Area metaxylem elem. $\left(\mu \mathrm{m}^{2}\right)$ & $256.3 \mathrm{a}$ & $240.2 \mathrm{a}$ & $168.6 \mathrm{~b}$ \\
No. protoxylem elements & $208.0 \mathrm{~b}$ & $278.6 \mathrm{a}$ & $292.8 \mathrm{a}$ \\
\hline $\begin{array}{l}\text { Traqueary elemens cell wall } \\
(\mu \mathrm{m})\end{array}$ & $3.5 \mathrm{~b}$ & $5.0 \mathrm{a}$ & $5.2 \mathrm{a}$ \\
Cortical cell wall $(\mu \mathrm{m})$ & $1.5 \mathrm{~b}$ & $3.5 \mathrm{a}$ & $3.7 \mathrm{a}$ \\
\hline
\end{tabular}

Means followed by the same letter in the column do not differ (Tukey test, $p \leq 0.05 ; \mathrm{n}=5$ ).

induced by metals affected the epidermis tissue, which presented relatively thin walls in relation to the exodermis, potentially being the cause of cell degradation in the roots of contaminated treatments. The loss of root epidermis and consequent substitution of its functions by the exodermis occurs in many species, like Ranunculus sp., where the exodermis it works as coating (Raven et al., 2001).

Analysis of fluorescence revealed a lignin deposit on the walls of cortical cells in roots exposed to the treatment with contamination at $15 \%$, absent in the other treatments (Figure 5). Roots of plants cultivated in contaminated soil presented changes in size, shape and arrangement of cortical parenchyma cells (Figure 4). Particularly, plants of the treatment with more contamination had widened cell spaces in the cortex that were virtually always present where death of parenchyma cells was observed. Intercellular spaces formation and changes in the cellular arrangement are common in brachiaria resulting from root maturation. Besides the cell degeneration induction, changes in cell shape and organization suggests a heavy metal interference in the root maturation rate, probably due to the ability of heavy metal disrupt the hormonal balance (Barceló et al., 1990; Sandalio et al., 2001).

Being apoplastic barriers, the exodermis and the endodermis play important parts in the protection against various types of stress (Enstone et al., 2003). The thickening of these tissues in $B$. decumbens could be a plant strategy to minimize the translocation of metals. High proportions of exodermis and endodermis tissue in plant roots characterize high tolerance to heavy metals (Lux et al., 2004). The development of a tertiary cell wall is typical of monocotyledons, and the maturation of Casparian bands is quickly followed by the deposition of a suberin lamella and the formation of a cellulose layer (Enstone et al., 2003). The development of successional stages of exodermis and endodermis observed in this study could indicate a better ability for barring apoplastic metal flow. However, the thickening of cell walls in the root provides a greater area for retention of heavy metals, decreasing their translocation to the shoot part. Additionally, with the matura- tion of Casparian bands in the exodermis there is a reduction in the membrane surface available for ion absorption (Enstone et al., 2003).

The additional lignin deposit in the endodermis cells that was observed in the treatment exposed to the highest contamination level $\left(15 \% \mathrm{~m}^{3} \mathrm{~m}^{-3}\right)$ contributed a new layer of material that does not affect the radial transport of ions that usually move freely via the symplast, such as $\mathrm{K}^{+}$and $\mathrm{PO}_{4}^{3-}$, but inhibits the movement of ions that flow mainly via the apoplastic route (Russel and Clarkson, 1975), which is the case for most heavy metals. Lignin deposition in cortical cell walls can help maintain root turgescence as it reduces water loss from the root by reflux. This turgescence is essential for root activity maintenance. Lignification of cellulose microfibrils in the cell walls is an adaptive mechanism that helps maintain the stability of the root architecture (Hose et al., 2001) and, according to Gaspar and Coumans (1987), the morphological and functional quality of the root system relates to the lignin content in its tissues. Additionally, as the root is a deposition site for heavy metals, expanded cell wall areas positively favor higher metal retention. Heavy metals have frequently been found in cortical cell walls (Wójcik et al., 2005). Cell walls have been found to be the first barrier protecting the protoplast against the toxicity of metals such as $\mathrm{Cd}$, and metal allocation in the cell walls is an important tolerance mechanism, especially in low concentrations and for short exposure periods (Wójcik et al., 2005).

Although toxicity causes cell degeneration in root tissues, the widened intercellular spaces in the cortical parenchyma, as caused by contamination, can suggest greater metal allocation capacity in the roots and lower transfer to the shoot part. Occurrence of metals such as $\mathrm{Cd}$ has been verified in the apoplast (cell walls and intercellular spaces) of the cortical parenchyma of roots (Wójcik et al., 2005), and metal adsorption in intercellular spaces is probably a strategy of accumulator species.

The tracheary elements of the xylem and cortical parenchyma of roots exposed to contaminated soil presented thicker walls than the control (Table 2; Figures 4 D-F). The roots in contaminated treatments also presented a larger number of tracheary elements in the vascular cylinder (Table 2). The area of metaxylem elements, however, was found to be smaller in the treatment with contamination at $15 \%$, not differing in the other treatments.

In $B$. decumbens the wall thickening of both xylem elements and cortical parenchyma roots is another anatomical adaptation to heavy metals toxicity. Some authors suggest that in plant, the capacity to bind heavy metal in the cell wall has a protective action against the deleterious effect of heavy metals by reducing the amounts of cytosolic heavy metals (Vázquez et al., 1992; Wójcik et al., 2005). However, wall thickening can help maintain the hydraulic safety of the root, essential for its activity in that it constitutes a barrier to water loss by reflux. This adaptation could also be associated to the capability to accumulate heavy metals by blocking ion reflux, particularly during periods of low or absent transpiration processes. According to Enstone et al., (2003), the ions accumulate in the root apoplast more rapidly than they are removed by transpiration transport, developing osmotic stresses that will favor flow in the opposite direction of the vascular cylinder. 
Changes the number of tracheary elements and metaxylem area as observed in this study can be associated to the promoted root maturation by heavy metals as a result of the hormone balance alteration. Heavy metals can affect the balance of root hormones, which in turn can affect tissue morphogenesis, also influencing the number of cells in these tissues (Barceló et al., 1990; Sandalio et al., 2001). Furthermore, the large number of tracheary elements and the reduction on metaxylem area change the hydraulic capacity. Vessels of larger diameter are more efficient but less safe due to the increased risk of blisters (Dickison, 2000).

\section{Anatomical responses of the leaf}

Leaves of $B$. decumbens presented bulliform cells on the adaxial side, these cells being larger than ordinary cells. Stomata are distributed on of the leaf both sides. In the mesophyll, which is composed by chlorophyll parenchyma, the cells are radially arranged around the bundles (Kranz anatomy), with the endodermis internally (bundle sheath). The endodermis is simple and internally to it is a uniseriate and sclerenchymatous pericycle. Larger bundles presented subepidermal sclerenchyma caps on the adaxial and abaxial sides, connected to the bundle and forming bundle sheath extensions.

The leaves of plants exposed to contamination presented modified anatomical characteristics (Figure 3). The epidermis of the adaxial and abaxial sides thickened as contamination
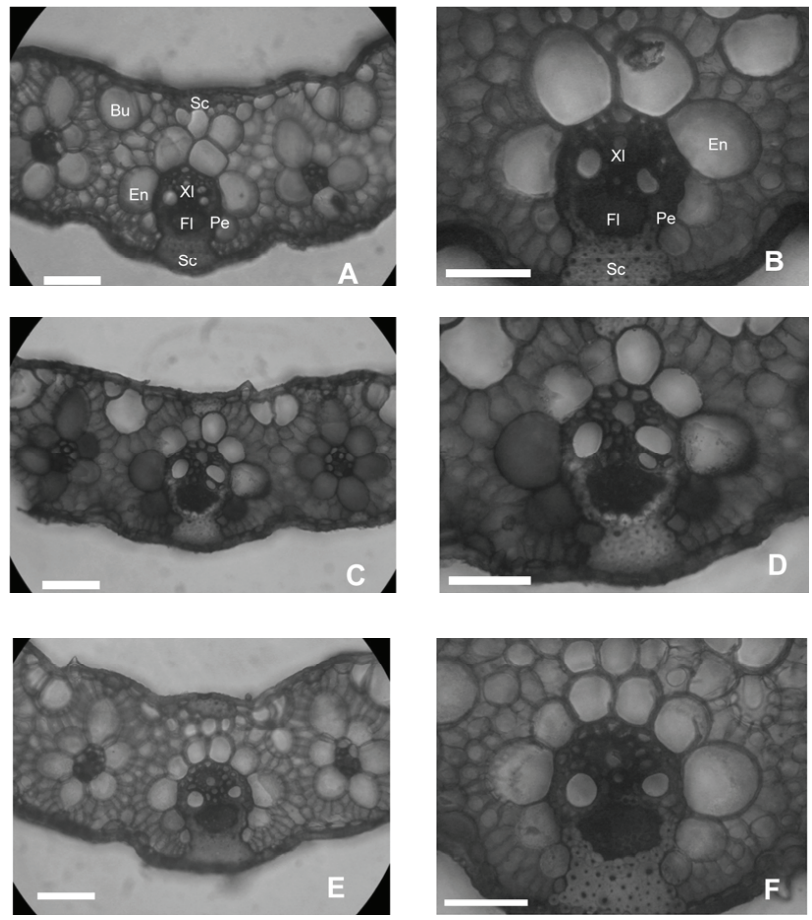

Figure 3 - Cross sections of midrib of leaf blade in $B$. decumbens plants submitted to levels of soil contamination from heavy metals. $\mathrm{A}$ and $\mathrm{B}=$ control; $\mathrm{C}$ and $\mathrm{D}=$ contamination at $7.5 \% ; \mathrm{E}$ and $\mathrm{F}=$ contamination at $15 \%$. Bu $=$ bulliform cells; $\mathrm{En}=$ endodermis; $\mathrm{Fl}=$ phloem; $\mathrm{Pe}$ $=$ pericycle; $\mathrm{Sc}=$ sclerenchyma $\mathrm{Xl}=$ xylem. Scale bars correspond to $50 \mu \mathrm{m}$. increased (Table 3). The dimension (width and height) of bulliform cells was greater in leaves exposed to contamination at 15 $\%$ (Table 3). The leaf blade presented smaller thickness in the treatments exposed to contamination (Table 3). No differences were observed among treatments for dimension (height and width) of the vascular bundle of the midrib, and the number of tracheary elements in the bundle was smaller in the treatment exposed to the highest contamination level (Table 3). The area of metaxylem elements was smaller in the treatment at $15 \%$, not differing in the other treatments.

A larger number of endodermis cells and a larger endodermis area were verified in the leaves of plants exposed to contaminated treatments (Table 3). The adaxial and abaxial sclerenchyma and pericycle were thicker in the treatment exposed to the highest contamination level (Table 3). To the abaxial face, the number of stomata per $\mathrm{mm}^{2}$ was greater in the treatment at $15 \%$, while the polar and equatorial diameter of stomata did not differ among treatments (Table 3). Already to the adaxial face, the number of stomata per $\mathrm{mm}^{2}$ was greater and polar and

Table 3 - Anatomical characteristics of leaf tissues in B. decumbens plants submitted to levels of soil contamination from heavy metals.

\begin{tabular}{lccc}
\hline & \multicolumn{3}{c}{ Treatment } \\
\cline { 2 - 4 } & 0 & 7.5 & 15 \\
\cline { 2 - 4 } & Contamination $\left(\%, \mathrm{~m}^{3} \mathrm{~m}^{-3}\right)$ \\
\hline Adaxial epidermis $(\mu \mathrm{m})$ & $6.4 \mathrm{~b}$ & $7.3 \mathrm{~b}$ & $9.4 \mathrm{a}$ \\
Abaxial epidermis $(\mu \mathrm{m})$ & $6.4 \mathrm{~b}$ & $9.0 \mathrm{a}$ & $9.2 \mathrm{a}$ \\
Bulliform cells width $(\mu \mathrm{m})$ & $73.4 \mathrm{~b}$ & $79.6 \mathrm{~b}$ & $107.1 \mathrm{a}$ \\
\hline Bulliform cells height $(\mu \mathrm{m})$ & $55.3 \mathrm{~b}$ & $54.8 \mathrm{~b}$ & $65.7 \mathrm{a}$ \\
Leaf blade thickness $(\mu \mathrm{m})$ & $179.6 \mathrm{a}$ & $165.2 \mathrm{~b}$ & $168.2 \mathrm{~b}$ \\
Vascular bundle height $(\mu \mathrm{m})$ & $70.5 \mathrm{a}$ & $78.1 \mathrm{a}$ & $78.6 \mathrm{a}$ \\
Vascular bundle width $(\mu \mathrm{m})$ & $61.1 \mathrm{a}$ & $64.7 \mathrm{a}$ & $66.5 \mathrm{a}$ \\
Traqueary elements no. & $21.0 \mathrm{a}$ & $18.8 \mathrm{a}$ & $15.8 \mathrm{~b}$ \\
Area metaxylem elements $\left(\mu \mathrm{m}^{2}\right)$ & $74.7 \mathrm{a}$ & $72.1 \mathrm{a}$ & $63.2 \mathrm{~b}$ \\
No. endodermis cells & $8.4 \mathrm{~b}$ & $10.6 \mathrm{a}$ & $11.2 \mathrm{a}$ \\
Endodermis area & $19.2 \mathrm{~b}$ & $26.7 \mathrm{a}$ & $26.9 \mathrm{a}$ \\
\hline Abaxial sclerenchyma $(\mu \mathrm{m})$ & $19.5 \mathrm{c}$ & $31.5 \mathrm{~b}$ & $36.5 \mathrm{a}$ \\
Adaxial sclerenchyma $(\mu \mathrm{m})$ & $7.3 \mathrm{~b}$ & $9.3 \mathrm{a}$ & $10.8 \mathrm{a}$ \\
Pericycle $(\mu \mathrm{m})$ & $10.1 \mathrm{~b}$ & $13.1 \mathrm{ab}$ & $14.5 \mathrm{a}$ \\
Stom. Dens. Ab. Ep. $\left(\mathrm{no} . / \mathrm{mm}^{2}\right)$ & $152.6 \mathrm{~b}$ & $166.1 \mathrm{ab}$ & $181.6 \mathrm{a}$ \\
PDSAbE $(\mu \mathrm{m})$ & $32.7 \mathrm{a}$ & $33.0 \mathrm{a}$ & $33.3 \mathrm{a}$ \\
EDSAbE $(\mu \mathrm{m})$ & $7.45 \mathrm{a}$ & $7.52 \mathrm{a}$ & $7.60 \mathrm{a}$ \\
Stom. Dens. Ad. Ep. $\left(\mathrm{no} . / \mathrm{mm}^{2}\right)$ & $173.4 \mathrm{~b}$ & $199.3 \mathrm{a}$ & $201.5 \mathrm{a}$ \\
PDSAdE $(\mu \mathrm{m})$ & $31.8 \mathrm{a}$ & $18.3 \mathrm{~b}$ & $18.3 \mathrm{~b}$ \\
EDSAdE $(\mu \mathrm{m})$ & $6.3 \mathrm{a}$ & $2.0 \mathrm{c}$ & $4.2 \mathrm{~b}$ \\
\hline & & & \\
& & &
\end{tabular}

Stom. Dens. Ab. Ep. = stomatic density of abaxial epidermis; PDSAbE = polar diameter of stomata of abaxial epidermis; $\mathrm{EDSAbE}=$ equatorial diameter of stomata of abaxial epidermis; Stom. Dens. Ad. Ep. = stomatic density of adaxial epidermis; PDSAdE = polar diameter of stomata of adaxial epidermis; EDSAdE = equatorial diameter of stomata of abaxial epidermis. Means followed by the same letter in the column do not differ (Tukey test, $p \leq 0.05 ; \mathrm{n}=3$ ). 

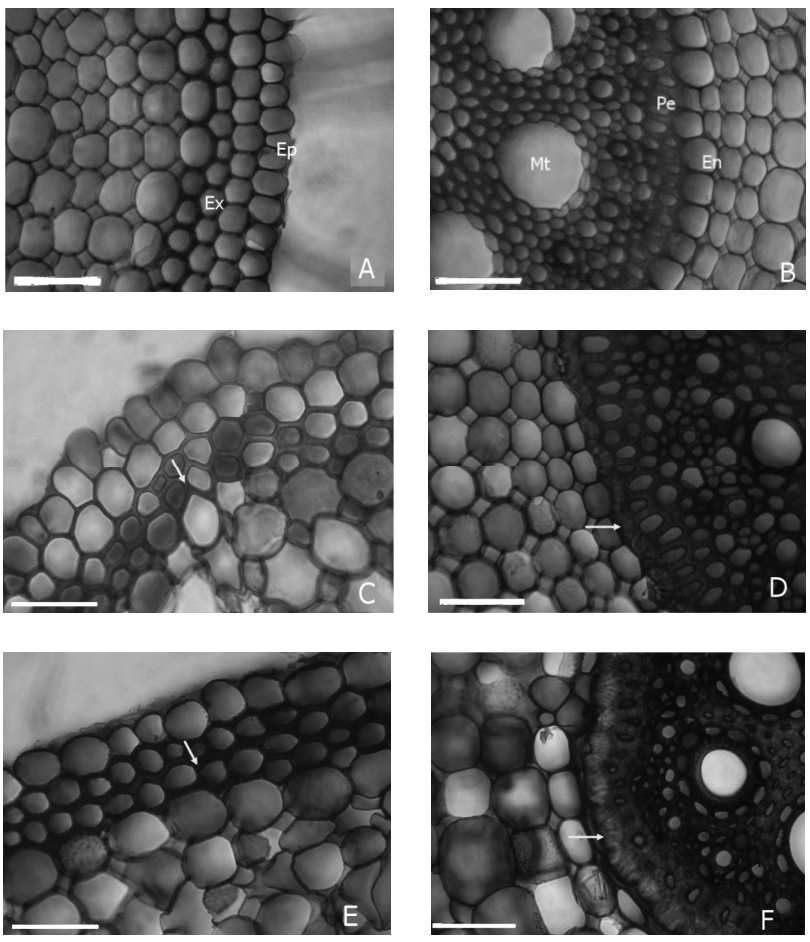

Figure 4 - Cross sections of root in $B$. decumbens plants submitted to levels of soil contamination from heavy metals. $\mathrm{A}$ and $\mathrm{B}=$ control; $\mathrm{C}$ and $\mathrm{D}=$ contamination at 7.5 $\% ; \mathrm{E}$ and $\mathrm{F}=$ contamination at $15 \% . \mathrm{Cp}=$ cortical parenchyma; $\mathrm{En}=$ endodermis; $\mathrm{Ep}=$ epidermis; $\mathrm{Ex}=$ exodermis; $\mathrm{Mt}=$ metaxylem; $\mathrm{Pe}=$ pericycle. Arrows indicate lignin deposition in treatments exposed to contamination which is characteristic of endodermis and exodermis cell wall maturation. Scale bars correspond to $50 \mu \mathrm{m}$.

equatorial diameter of stomata was smaller in the contamination treatments (Table 3).

The heavy metals absorbed by the plant are mostly accumulated in the roots, and anatomical adaptations were observed in $B$. decumbens in order to tolerate metal concentrations in its tissues. Although leaf tissues retained lower concentrations of heavy metals, anatomical adaptations were, nevertheless, noted in leaves of $B$. decumbens. The thickened adaxial and abaxial epidermis and the larger bulliform cells found in the species can be a strategy to minimize water loss by transpiration, also relating to the greater leaf blade turgor that was observed in the plants exposed to contamination. Additionally, being closely related to root absorption, lower transpiration rates imply reduced acquisition of metal ions. Leaf curling can be a strategy to reduce the transpiration area on the surface, keeping stomata in a humid microclimate and thus preventing dryness (Turner and Jones, 1980). Size variations in epidermal tissues and bulliform cells in response to air pollution and water deficit conditions have been reported in literature (Alves et al., 2001; Melo et al., 2007).

Exposure to heavy metals leads to a reduction in the size of mesophyll cells (Srighar et al., 2005; Zhao et al., 2000) and the collapse of palisade and spongy parenchyma cells (Sirdhar et al., 2005), which could justify the thinned leaf
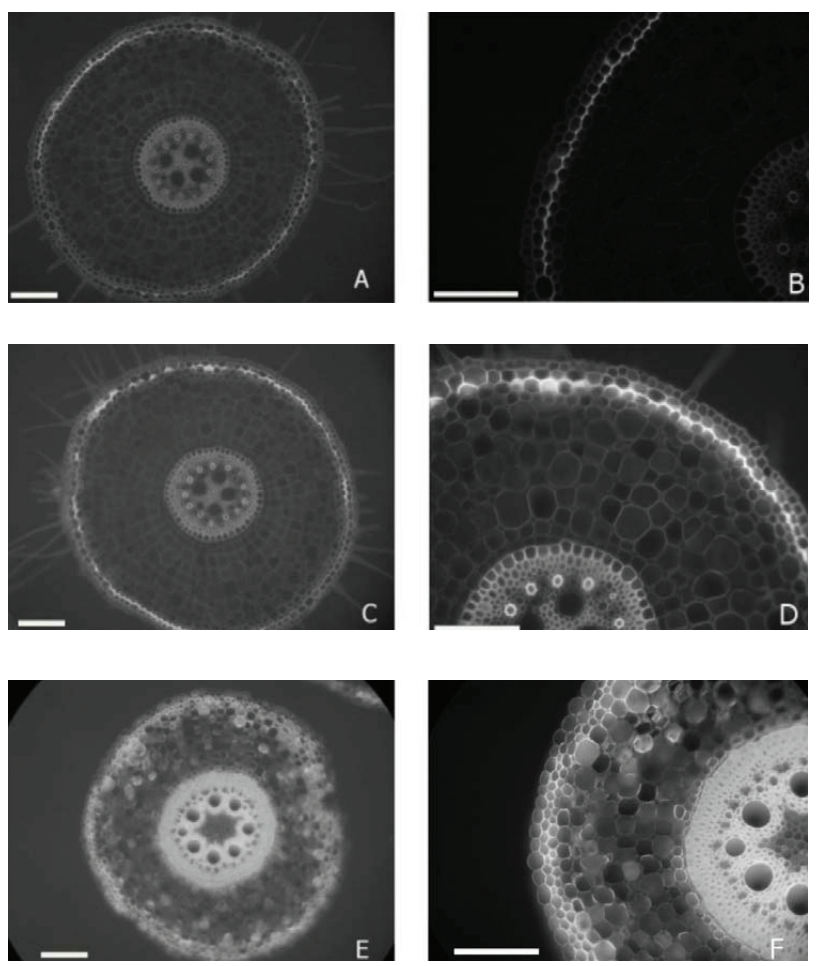

Figure 5 - Fluorescence photomicrography for lignin detection in root sections of $B$. decumbens plants submitted to levels of soil contamination from heavy metals. A and B $=$ control; $\mathrm{C}$ and $\mathrm{D}=$ contamination at $7.5 \%$; $\mathrm{E}$ and $\mathrm{F}=$ contamination at $15 \%$. Fluorescent areas indicate lignin deposition in the walls. Scale bars correspond to $50 \mu \mathrm{m}$.

blade observed in the treatments exposed to contamination. Conditional on anatomical plasticity, some species develop modified leaf tissues that allow better adaptability to different stress conditions (Melo et al., 2007). Reduction in the number of conducting elements has been reported in literature as being an adaptive measure to secure water flow (Baas et al., 1983). Reduction in size and number of conducting elements of the xylem in response to heavy metals has been reported by Sandalio et al. (2001).

The species studied here is a $\mathrm{C}_{4}$ plant, and thus it has been quite encompassing endodermis cells that occupy a large part of the mesophyll, which is where the final $\mathrm{CO}_{2}$ fixation stage occurs. Reduced thickness of the leaf blade in $B$. decumbens is due to the reduced cell size of the chlorophyll parenchyma, not followed by the leaf endodermis. The increase in a number of cells and area of endodermis could thus be a compensatory mechanism for the loss of the photosynthetic area due to a reduced leaf parenchyma. Also, considering its filtering function, the increase in the number of cells and area of the endodermis could be an adaptive measure to lower metal translocation to the chlorophyll parenchyma, preventing possible damage to the primary $\mathrm{CO}_{2}$ fixation system.

The increased thickness of the abaxial and adaxial sclerenchyma and pericycle tissues in B. decumbens, as caused by heavy metals, could be related to adsorption of metals in the cell walls, 
constituting an alternative pathway for allocation of these ions and preventing their translocation to photosynthetic tissues. Indeed, directing the deposition of heavy metals to non-photosynthetic tissues could be a plant strategy to tolerate toxic levels of heavy metals. In a study with Salix viminalis cultivated in the presence of Cd, Vollenweider et al. (2006) observed thickened walls of the collenchymas and pericycle, with higher concentrations of metal than the other tissues. According to the author, metal distribution among leaf tissues tends to occur as a means of minimizing its concentration in the chlorophyll parenchyma, preventing damage to the photosynthesis. An increased proportions of these tissues could also justify greater leaf turgor in the treatments exposed to contamination.

Researchers have reported increased stomatic density in leaves exposed to conditions of stress from heavy metals such as Cd (Baryla et al., 2001; Chardonnens et al., 1998). The increased stomatic density observed in this study could be a compensatory measure to the reduced transpiration area in turn resulting from the leaf curling observed in the treatments exposed to contamination, ensuring the maintenance of $\mathrm{CO}_{2}$ flow without major harm to the photosynthesis. Abrams et al. (1994) correlates the stomatal cell length with stomatal conductance. Smaller stomata present greater stomatal resistence, which would result in less water loss through transpiration. According to Melo et al. (2007), the increase in stomatal density, coupled with the decrease in stomatal size, would be an alternative to adequate supply of $\mathrm{CO}_{2}$ for photosynthesis, without excessive water loss due to stomata with smaller pores. This may be an adaptation of plants in response to toxicity of heavy metals, as found for the adaxial epidermis. Leaf transpiration is closely related to rooting absoption and an increase in water loss throught leaf transpiration can thus mean an increase in the acquisition of metal ions.

Physiological and anatomical changes in response to heavy metals are clear indications of the ecophysiological impact that these ions exert on the plant community. Phenotypic plasticity is the key to their adaptive process to environmental conditions, each species having distinctive characteristics. According to the results, $B$. decumbens showed adaptive characteristics for survival in soil contaminated by heavy metals, suggesting that the species can be further investigated as a potential restorer of areas contaminated by these metals.

\section{Acknowledgements}

To the Fundação de Amparo à Pesquisa do Estado de Minas Gerais for providing financial support.

\section{References}

Abrams, M.D.; Kubiske, M.E.; Mostoller, S.A. 1994. Relating wet and dry year ecophysiology to leaf structure in contrasting temperature tree species. Ecology 75: 123-133.

Alloway, B.J.; Ayres, D.C. 1997. Chemical Principles of Environmental Pollution. 2ed. Blackie Academic \& Professional, London, UK.

Alves, E.S.; Giusti, P.M.; Domingos, M. 2001. Anatomic studies on Trandescantia hibrid clone 4430 leaves: changes caused by urban air pollution. Revista Brasileira de Botânica 24: 561-566. (in Portuguese, with abstract in English).

Arnon, D.I. 1949. Cooper enzymes in isolated chloroplasts. Polyphenoloxidase in Beta vulgaris. Plant Physiology 24: 1-15.
Barceló, J.; Vázquez, M.D.; Poshenrieder, C.H. 1990. Plant water relations as affected by heavy metal stress: a review. Journal of Plant Nutrition 13: 1-37.

Baryla, A.; Carrier, P.; Franck, F.; Coulomb, C.; Sahut, C.; Havaux, M. 2001. Leaf cloroses in oilseed rape plants (Brassica napus) grown o cadmiumpolluted soil: causes and consequences for photosynthesis and growth. Planta 212: 696-709.

Baas, P.; Werker, E.; Fahn, A. 1983. Some ecological trends in vessel characters. IAWA Bulletin 4: 141-159.

Brundrett, M.C.; Enstone, D.E.; Peterson, C.A. 1988. A barberine: aniline blue fluorescent staining procedure for suberin, lignin, and callose in plant tissue. Protoplasma 146: 133-142.

Cagno, R.; Guidi, L.; De Gara, L.; Soldatini, G.F. 2001. Combined cadmium and ozone treatments affect photosynthesis and ascosbate defences in sunflower. New Phytologist 151:.627-636.

Cagno, R.; Guidi, L.; Stefani, A.; Soldatini, G.F. 1999. Effects of cadmium on growth of Helianthus annuus seedlings: physiological aspects. New Phytologist 144: 65-71.

Carneiro, M.A.C.; Siqueira, J.O.; Moreira, F.M.S. 2001. Establishment of herbaceous plants in soils contaminated with heavy metals and inoculation with mycorrhizal fungi. Pesquisa Agropecuária Brasileira 36: 1443-1452. (in Portuguese, with abstract in English).

Chardonnens, A.N.; Ten Bookum, W.M.; Kuijper, D.J.; Verkleij, J.A.C.; Ernst, W.H.O. 1998. Distribution of cadmium in leaves of cadmium tolerant and sensitive ecotypes of Silene vulgaris. Physiology Plantarum 104: 75-80.

Chugh, L.K.; Sawhney, S.K. 1999. Photosynthetic activities of Pisum sativum seedlings grown in presence of cadmium. Plant Physiology and Biochemistry 37: 297-303.

Dickison, W.C. 2000. Ecological anatomy. In Dicksison, W.C. Integrative plant anatomy. Academic Press, San Diego, CA, USA.

Ederli, L.; Reale, L.; Ferranti, F.; Pasqualini, S. 2004. Responses induced by high concentration of cadmium in Phragmites australis roots. Physiologia Plantarum 121: 66-74.

Enstone, D.E.; Peterson, C.A.; Ma, F. 2003. Root endodermis and exodermis: Structure, function, and responses to the environment. Journal of Plant Growth Regulation 21: 335-351.

Ferreira, D.F. 1999. SISVAR 4.3: Statistical Analysis System. UFLA, Lavras, MG, Brazil.

Fontes, R.L.F.; Cox, F.R. 1998. Iron deficiency and zinc toxicity in soybean grown in nutrient solution whith different levels of sulfur. Journal of Plant Nutrition 21: 1715-1722.

Forster, J.C. 1995. Heavy metals. In: Alef, K.; Nannipieri, P. Methods in applied soil microbiology and biochemistry. Academic Press, London, UK.

Gaspar, T.; Coumans, M. 1987. Root formation. p. 202-217. In: Bonga, J.M.; Durzan, D.J., eds. Cell ad tissues culture in forestry. Martins Nijhoff, The Hague, The Netherlands.

Horváth, G.; Droppa, M.; Orazeez, A.; Raskin, V.I.; Arder, J.B. 1996. Formation of the photosynthetic apparatus during greening of cadmiumpoisoned barley leaves. Planta 199: 238-243.

Hose, E.; Clarkson, D.T.; Steudle, L.; Hartung, W. 2001. The exodermis: a variable apoplástica barrier. Journal of Experimental Botany 52: 22452264.

Johansen, D.A. 1940. Plant microtechinique. 2ed. McGraw-Hill, New York, NY, USA.

Kabata-Pendias, A.; Pendias, H. 2001. Trace elements in soils and plants. 3ed. Boca Raton: CRC Press, FL, USA.

Kraus, J.E.; Arduin, M. 1997._Basic Manual of Methods in Plant Morphology. EDUR, Seropédica, RJ, Brazil. (in Portuguese).

Lux, A.A.; Sottniková, A.; Opatrná, J.; Greger, M. 2004. Differences in struture of adventitions roots in Salix clones with contrasting characteristics of cadmium accumulation and sensitivity. Physiologia Plantarum 120: 537-545.

MacFarlane, G.R.; Burchett, M.D. 2000. Cellular distribuition of copper, lead and zinc in the grey mangrove, Avicennia marina (Forsk.) Vierh. Aquatic Botany 68: 45-59.

Marques, T.C.L.L.S.M.; Moreira, F.M.S.; Siqueira, J.O. 2000. Growth and uptake of metals in tree seedlings in soil contaminated with heavy metals. Pesquisa Agropecuária Brasileira 35: 121-132. (in Portuguese, with abstract in English). 
Melo, H.C.; Castro, E.M.; Soares, A.M.; Melo, L.A.; Alves, J.D. 2007. Anatomical and physiological alterations in Setaria anceps Stapf ex Massey and Paspalum paniculatum $L$. under water deficit conditions. Hoehnea 34: 145-153. (in Portuguese, with abstract in English).

Prasad, M.N.V.; Malec, P.; Waloszek, A.; Bojko, M.; Strzałka, K. 2001. Physiological responses of Lemna trisulca L. (duckweed) to cadmium and copper bioaccumulation. Plant Science 161: 881-889.

Raven, P.H.; Evert, R.F.; Eichhorn, S.E. 2001._Root: structure and development . p. 567-585. In: Raven, P.H.; Evert, R.F.; Eichhorn,S.E., eds. Biology of plants. 6ed. Guanabara Koogan, Rio de Janeiro, RJ, Brazil. (in Portuguese).

Russel, R.S.; Clarkson, D.T. 1975. Ion transport in root systems. p. 401-411. In: Sunderland, N., ed. Perspectives in experimental biology. 2. Botany. Pergamon Press, Oxford, UK.

Sandalio, L.M.; Dalurzo, H.C.; Gómes, M.; Romero-Puertas, M.C.; Del Rio, L.A. 2001. Cadmium-induced changes in the growth and oxidative metabolism of pea plants. Journal of Experimental Botany 52: 21152126.

Sanitá di Troppi, L.; Gabbrielli, R. 1999. Response to cadmium in higher plants. Environomental of Experimental Botany 41: 105-130.

Sheoran, I.S.; Agarwal, N., Singh, R. 1990a. Effect of cadmium and nickel on in vivo carbon dioxide exchange rate of pigeonpea (Cajanus cajan L.). Plant Soil 129: 243-249.

Sheoran, I.S.; Singal, H.R.; Singh, R. 1990b. Effect of cadmium and nickel on photosynthesis and the enzymes of the photosynthetic carbon reduction cycle in pigeonpea (Cajanus cajan L.). Photosynthetic Research 23: 345-351.

Silva, S.; Siqueira, J.O.; Soares, C.R.F.S. 2006. Mycorrhizal fungi influence on brachiariagrass growth and heavy metal extraction in a contaminated soil. Pesquisa Agropecuária Brasileira 41: 1749-1757. (in Portuguese, with abstract in English).

Singh, S.; Eapen, S.; D’Souza, S.F. 2006. Cadmium accumulation and its influence on lipid peroxidation and antioxidative system in an aquatic plant Bacopa monnieri L. Chemosphere 62: 233-246.
Skorzynska-Polit, E.; Drazkiewicz, M.; Krupa, Z. 2003. The activity of the antioxidative system in cadmium treated Arabidopsis thaliana. Biologia Plantarum 47: 71-78.

Srighar, B.B.M; Diehl, S.V.; Han, F.X.; Monts, D.L.; Su, Y. 2005. Anatomical changes due to uptake and accumulation of $\mathrm{Zn}$ and $\mathrm{Cd}$ in Indian mustard (Brassica juncea). Environmental and Experimental Botany 54: 131-141.

Stobart, A.K.; Griffiths, W.T.; Ameen-Bukhari, I.; Sherwood, R. 1985. The effect of $\mathrm{Cd}^{2+}$ on the biosynthesis of chlorophyll in leaves of barley. Physiologia Plantarum 63: 293-298.

Turner, N.C.; Jones, M.M. 1980. Turgor maintenance by osmotic adjustment a review and evolution. p. 87-104. In: Turner, N.C.; Kramer, P.J., eds. Adaptation of plant to water and high temperature stress. Wiley, New York, NY, USA.

Vázquez, M.D.; Poschenrieder, C.; Barceló, J. 1992. Ultra structural effects and localization of low cadmium concentrations in bean roots. New Phytologist 140: 350-355.

Vollenweider, P.; Cosio, C.; Günthardt-Goerg M.; Keller, C. 2006. Localization and effects of cadmium in leaves of a cadmium-tolerant willow (Salix viminalis L.). II. microlocalization and cellular effects of cadmium. Environmental of Experimental Botany 58: 25-40.

Wójcik, M.; Vangronsveld. J.; D’Haen, J.; Tukiendorf, A. 2005. Cadmium tolerance in Thlaspi caerulescens. Environmental of Experimental Botany 53: 163-171.

Zhao, F..; Lombi, E.; Breedon. T.; McGrath, S.P. 2000. Zinc hyperaccumulation and cellular distribution in Arabidopsis halleri. Plant Cell and Environmental 23: 507-514.

Zhou, W.; Qiu, B. 2005. Effects of cadmium hyperaccumulation on physiological characteristics of Sedum alfredii Hance (Crassulaceae). Plant Science 169: 737-745.

Received March 10, 2010

Accepted March 11, 2011 